IRA-International Journal of Management \& Social Sciences

ISSN 2455-2267; Vol.07, Issue 01 (2017)

Pg. no. 52-64

Institute of Research Advances

https://research-advances.org/index.php/RAJMSS

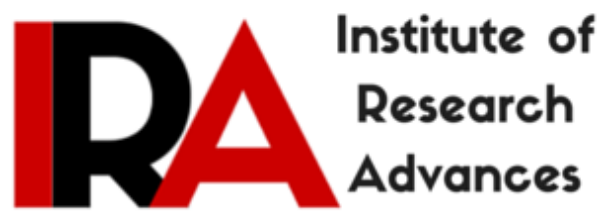

\title{
The Effect of Leadership, Organisational Culture and Work Motivation on Job Satisfaction and Job Performance among Civil Servants in Maros District Technical Working Unit
}

\author{
Dahlan Habba ${ }^{1}$, Basri Modding ${ }^{2}$, Muh. Jobhaar Bima ${ }^{3}$, Jamaluddin Bijang ${ }^{4}$ \\ ${ }^{1)}$ School of Management Sciences, the Islamic College Foundation Maros (STIM \\ YAPIM) \\ Doctoral Student in the Faculty of Economics, the Muslim University of Indonesia \\ ${ }^{2,3,4)}$ Faculty of Economics, the Muslim University of Indonesia
}

Type of Review: Peer Reviewed.

DOI: http://dx.doi.org/10.21013/jmss.v7.n1.p7

\section{How to cite this paper:}

Habba, D., Modding, B., Bima, M., \& Bijang, J. (2017). The Effect of Leadership, Organisational Culture and Work Motivation on Job Satisfaction and Job Performance among Civil Servants in Maros District Technical Working Unit. IRA-International Journal of Management \& Social Sciences (ISSN 2455-2267), 7(1), 52-64. doi:http://dx.doi.org/10.21013/jmss.v7.n1.p7

(C) Institute of Research Advances

\section{(cc) EY-NC}

This work is licensed under a Creative Commons Attribution-Non Commercial 4.0 International License subject to proper citation to the publication source of the work.

Disclaimer: The scholarly papers as reviewed and published by the Institute of Research Advances (IRA) are the views and opinions of their respective authors and are not the views or opinions of the IRA. The IRA disclaims of any harm or loss caused due to the published content to any party. 


\begin{abstract}
This study was analyzes the effect of leadership, organizational culture and work motivation on job satisfaction and performance of employees in the Maros technical working units. 245 civil servants were included in this study sample. The results of hypothesis testing with support Analysis of Moment Structures Ver.20 provides evidence that leadership and organizational culture are well proven to increase job satisfaction, but was unable to encourage the creation of civil servants performance. Job satisfaction has no significant role in explaining the influence of leadership and organizational culture on civil servants performance. A civil servant work motivation is at a high level is proven to increase job satisfaction and create improved civil servants performance. Job satisfaction has a significant role in explaining the effect of work motivation on civil servants performance. The High level of civil servants job satisfaction is what determines the creation of civil servants performance.
\end{abstract}

Keywords: leadership, organizational culture, motivation, job satisfaction, performance

\title{
Introduction
}

The implementation of the tasks and governance influenced by leadership, organizational culture and motivation, which in turn will create job satisfaction and improve civil servants performance is a key part of the success of the government bureaucracy. Through the leadership and organizational culture supported by the capacity for good governance, the implementation of good governance will be realized, otherwise lack the capabilities of leadership is one of the low performance of bureaucracy in Indonesia (Istianto, 2009: 2). Good governance issues the most prominent in the management of public administration today. Vociferous demands made by the people to the government for good governance held in line with the increasing knowledge of local communities with the influence of globalization demands openness. An old pattern of governance no longer relevant to society has changed. Especially the Act Number 22 of 1999 on local government that has been revised to law No. 32 of 2004 and Law No. 25 of 1999 have been revised into Law No. 33 of 2004 on the balance of Finance between the Government and the Regional Center and then the Law of the No. 23 of 2014 on Regional Government.

Employee performance is the result of work in terms of quality, quantity and timeliness achieved by an employee in carrying out their duties in accordance with responsibility given to him that is not only influenced by the ability and expertise in working, but is also strongly influenced by the spirit of his (Mangkunegara, 2005: 9). Employee performance is a combination of ability, effort, and opportunities that can be measured from the consequences resulting, so performance is not only about the personal characteristics of an employee, but rather the result of work has been and will be conducted by an employee.

Maros district technical working unit is a system that consists of various components that are associated with each other in carrying out their respective functions. Therefore, each of the components is of keeping each other for the implementation of its functions run smoothly and organizational objectives can be achieved. Improvement and development of human resources through the regional work units that exist within an organization has an important role in achieving their stated objectives Vision and Mission of Local Government. A technical working unit is a system that consists of several components that have their respective roles in accordance with its function. This system involves people working together to achieve the same goal.

Those components are interconnected and interact with each other in realizing the objectives of 
the organization. In carrying out their daily duties of employees are required to comply with employment regulations. Therefore, every organization needs to have a variety of conditions that must be adhered to by its members, the standards which must be met, and needs to be addressed in order to improve quality and employee satisfaction to the job. Civil Service serves as an element of the state apparatus that served to provide public services in a professional, fair and equitable in enforce tasks, Civil Servants have a decisive role in the success of achieving the goal, which is key in determining the success or whether the government in carrying out its authority.

Maros technical working units which is one of the organizations of the Agency, the Department and the Office was instrumental in developing, improving quality and coordinate all public services in the community at the district level in accordance with the mandate of the Regional Regulation Maros No. 11 Year 2012 on Organization and Working Procedures Regional offices Scope of Maros government (Maros Regional Gazette of 2012 No. 11).

An employee is expected to play a role in creating a pattern of working procedures in carrying out official activities and be able to solve all problems related to Leadership, Organizational Culture, Motivation on Job Satisfaction and Performance of Regional Work Units in Maros district government sphere. But there are still quite a lot of gaps that are less fit with that, there are still some weaknesses shown by employees where they are less motivated to work. There is a lack of timely moment in the office, delaying work tasks, lack of discipline of time and could not take advantage of the good office facilities. This is what needs to get the attention of the managerial especially institutional leaders, as early as possible in order to prevent and seeks to improve the quality of human resource management that existed at the Maros technical working units.

Their employees are less concerned with what should be done and it is his responsibility, which should an employee who has a significant role in developing the potential to organize and establish the concept of maximum performance in service productivity which ultimately result in the fulfillment satisfied and unmet needs

Maros technical working units function very strategic in realizing the implementation of the structure and governance in the running of leadership, organizational culture and work motivation to achieve job satisfaction and improved employee performance within the scope of the regional work units Maros district government. Therefore, efforts to increase of job satisfaction and civil servants performance at the local government unit worthy actual issues to improve the effectiveness of the implementation of the tasks and functions of the institution so that the employee's performance should be viewed as a cultural phenomenon that can be influenced by various factors.

From the internal point of employees in the Maros technical working units Gives an overview of the state of the Civil Service has a strong commitment to enhancing the professionalism of the Human Resources Administrative Regions in order to support the achievement of development goals regions. Commitment can be achieved through such employee performance, organizational authority, organizational structure, job descriptions, organizational functions, organizational planning, leadership, organizational culture, motivation, and other factors, such as monitoring, employee training and infrastructure adequate employee

Reality shows that in the implementation of leadership, organizational culture and motivation can be factors that influence job satisfaction and employee performance on the Maros technical working units. The statement refers to the main elements of is leadership as leadership a determinant for success of all employees at the Maros technical working units. 


\section{Literature review and hypothesis development Leadership}

Leadership is different from management. Management is concerned with things to cope with complexity. Good management can result in the discipline and consistency to draw up formal plans, designing a tight organizational structure and monitor the results through benchmarking against predetermined plans. Leadership, by contrast, deals with matters to cope with change. Leaders set the direction by developing a vision for the future, then communicating to everyone and inspire these people in the face of all odds. Strong leadership and strong management is an important factor for optimizing the effectiveness of the organization (Robbins, 2006: 421).

Leadership is the ability to influence a group toward achievement of goals (Robbins, 2006: 432). In carrying out the process of leadership are usually individuals who do that are required to have the soul of a leader as a human person. The leader is a person who has the skills and strengths in one area, so he was able to influence others to jointly undertake certain activities in order to achieve one or more goals. Indicators used as a measurement of leadership, including: (1) instruction, (2) consulting, (3) participation, and (4) delegations (Kartono, 2001: 33).

Some previous research provides evidence that leadership is a significant and positive effect on employee job satisfaction (Suryana et al., 2009; Omar, WW, 2013; Belias \& Koustelios, 2014; Indra Hidayatullah, 2014). Other causality, based on previous research findings prove that the leadership has a positive effect on employee performance (Thoyib, A., 2005; Nur Azlina, 2007; Kistoyo 2008; Handri Wahyuni, 2008; Sukardi, 2009; Suryana et al., 2009; Abbas \& Yaqoob, 2009; Twelve, J, 2013).The findings were obtained denials from other researchers that leadership is not significant effect on employee performance (Putu Sunarcaya, 2008). Based on this evidence, and then formulated the hypothesis, as follows:

$\mathrm{H}_{1 \mathrm{a}}$ : Leadership has a positive and significant impact on employees job satisfaction

$\mathrm{H}_{1 \mathrm{~b}}$ : Leadership is a positive and significant impact on employee performance

\section{Organizational Culture}

Organizational culture is a set of assumptions or system of beliefs, values, and norms developed within the organization guiding the behavior of its members to overcome the problem of external adaptation and internal (Mangkunegara, 2000: 113). Organizational culture is a shared system of every member of the organization, which is done in a different way in each organization.

Organizational culture can provide guidelines for an employee about how he can perceive the characteristics of the organizational culture, values required of employees in work, interact with groups, systems and administration, as well as how to interact with your boss. Measurement of organizational culture in this study are described through; (1) innovation and risk taking, (2) accuracy, (3) results orientation, (4) human orientation, (5) organization and team, (6) aggressiveness, and (7) the stability (Soedjono, 2005).

Some previous research findings, that the organizational culture has a positive and significant impact on job satisfaction (Soedjono, 2005; Abdullah, 2006). Influences among other variables constructed in this study, based on previous research findings prove that organizational culture influence on employee performance (Ma'rifah, D., 2004; Thoyib, A., 2005; Soedjono, 2005; Abdullah, 2006; Tjahjono, BN 2006). Based on this evidence, and then formulated the hypothesis, as follows:

$\mathrm{H}_{2 \mathrm{a}}$ : Organizational culture is a positive and significant effect on employee job satisfaction

$\mathrm{H}_{2 \mathrm{~b}}$ : Organizational culture has a positive and significant effect on employee performance. 


\section{Work motivation}

Motive is defined as an inclination to move, starting from a boost in self and ends with adjustment (Sperling, 1987). Motive is a requirement that stimulated goal-oriented individuals in achieving a sense of satisfaction (William J. Stanton, 1981). Luthans (2002) asserts that motivation is a process that generates, encourage, direct, and sustain behavior and performance, that is to say, it is the process of stimulating people to act and to perform a desired task. One way to motivate individuals can do to make workers more satisfied so that workers have a commitment to their work.

Motivation is the willingness to use high-level effort in support of the achievement of organizational goals, which by conditioning your business's ability to meet the multiple needs of the individual. There are three (3) important elements namely; business, goals and needs. An element of the business is the intensity measurement. Effort directed towards and consistent with organizational objectives is a type of business that should be sought, and the motivation is the process of fulfillment. This variable is measured by several indicators, including: (1) Level of career, (2) work environment, (3) Motivation from within, (4) responsibility, (5) opportunities, and (6) space to develop you (Robbins, 2001).

Empirical facts provide evidence that motivation has a positive and significant effect on job satisfaction (Suryana et al. 2009; Arifin et al., 2015; Juniantara \& Riana, 2016). Other causality built in this study provide evidence that work motivation has a positive effect on employee performance (Ma'rifah, D., 2004; Tjahjono, BN, 2006; Faith S., 2007; Nur Azlina, 2007; Putu Sunarcaya 2008; Handri Wahyuni 2008; Sukardi, 2009; Suryana et al., 2009; Prihantoro, A., 2012; Juniantara \& Riana, 2016; Murgianto et al., 2016). Based on this evidence, and then formulated the hypothesis, as follows:

$\mathrm{H}_{3 \mathrm{a}}$ : Work motivation has a positive and significant effect on employee job satisfaction.

$\mathrm{H}_{3 \mathrm{~b}}$ : Work Motivation has a positive and significant effect on employee performance

\section{Job Satisfaction}

Job satisfaction is a positive attitude toward work in a person. Basically the job satisfaction is an individual thing. Each individual will have a level of satisfaction varies according to the value system that applies to him. Usually people will feel satisfied with the work that has been or is being executed, if what is done is considered to have met the expectations, in line with the objective to work.

Job satisfaction is an emotional state that is pleasant or unpleasant which employees view their work. Job satisfaction is a reflection of the feelings of workers to work. This is evident in a positive attitude towards work facing workers and the environment. Conversely, a disgruntled employee will act negatively toward work and form different from one another. Employee dissatisfaction should be detected by the company (Handoko, 1992: 193). Factors - factors that can be used as an indication of declining job satisfaction is absenteeism, turnover, and job performance (Muchinsky, 1997; 424).

Similar stated that the level of employee satisfaction due to the high level of absenteeism, high employee turnover, a decline in labor productivity or employee performance. If the indications of the decline in employee satisfaction rise to the surface, then it should be immediately addressed so as not to harm the organization (As'ad, 1995; 103). Measurement of job satisfaction develop measurement of Celluci \& David (1978), which consists of: (1) salaries, (2) working conditions, (3) co-workers, (4) challenge, (5) promotion, (6) the supervisor, and (7) the job itself

Some previous research findings, providing evidence that job satisfaction is positive and 
significant effect on employee performance (Jati, SP, \& Darmawan, D., 2005; Abdullah, 2006; Syaiin, S., 2008; Suryana et al., 2009; Asteria Putri \& Latrini, 2013; Arifin et al., 2015; Juniantara \& Riana, 2016). Based on this evidence, and then formulated the hypothesis, as follows:

$\mathrm{H}_{4}$ : job satisfaction has a positive and significant effect on employee performance

\section{Employee Performance}

Basically performance can be understood as the result of work that can be achieved by a person or group of people within an organization in accordance with the authority and responsibilities of each, in order to achieve the goals of the organization in question legally, does not violate the law, and in accordance with moral and ethical. Performance is defined as the combined behavior of the achievements of what is expected and the choice or part of the terms of the task on each individual in the organization (Walker, 2007). Performance is expressed as a result of the quality and quantity of work that can be accomplished by an employee in accordance with the responsibility of carrying out the task assigned to him (Mangkunegara, 2000). Employee performance measurement indicators developed using measurable indicators of Tsui et al. (1997), namely: (1) discipline and attendance, (2) professionalism, (3) the quantity, (4) responsibility, (5) electivity, (6) tenacity, (7) cooperation, and (8) concern.

Some previous researchers put job satisfaction as an intervening variable in analyzing the influence of leadership, organizational culture and work motivation on individual performance, that leadership is a positive influence on job satisfaction extra role performance (Yun,S. et al., 2007; Omar, WW, 2013), Organizational culture significantly influence organizational performance through satisfaction (Soedjono, 2005). Job satisfaction plays a role as a mediating variable in analyzing the effect of work motivation on performance (Murgianto et al., 2016). Based on this evidence, and then formulated the hypothesis, as follows:

$\mathrm{H}_{5 \mathrm{a}}$ : Leadership has a positive effect on performance through employee satisfaction

$\mathrm{H}_{5 \mathrm{~b}}$ : Organizational culture has a positive effect on performance through employee job satisfaction

$\mathrm{H}_{5 \mathrm{c}}$ : Work motivation has a positive effect on performance through employee satisfaction

\section{Results}

\section{Respondents}

Explanation of the characteristics of the respondents used to describe a description of the identity of respondents by sample set. The characteristics of respondents pliers used include: Age, Gender. Marital status, education level and job type and income respondents each month, for it can be shown as follows:

Table 1. Description of respondents

\begin{tabular}{|l|l|c|c|}
\hline \multicolumn{2}{|c|}{ Characteristics } & Frequency & Percent \\
\hline \multirow{4}{*}{ Gender } & Male & 117 & 47.8 \\
\cline { 2 - 4 } & Female & 128 & 52.2 \\
\hline \multirow{4}{*}{ Age } & $25-35$ years & 61 & 24.9 \\
\cline { 2 - 4 } & $35.1-45$ years & 92 & 37.6 \\
\cline { 2 - 4 } & $45.1-55$ years & 80 & $32.7>$ \\
\cline { 2 - 4 } & 55 & 12 & 4.9 \\
\hline
\end{tabular}




\begin{tabular}{|l|l|c|c|}
\hline \multirow{5}{*}{ Level of Education } & High School & 58 & 23.7 \\
& Diploma & 2 & .8 \\
\cline { 2 - 4 } & $\mathrm{S} 1$ & 142 & 58.0 \\
& $\mathrm{~S} 2$ & 42 & 17.1 \\
\hline & $\mathrm{S} 3$ & 1 & .4 \\
\hline \multirow{3}{*}{ Experience in work } & $1-10$ year & 72 & 29.4 \\
\cline { 2 - 4 } & $>11-20$ years & 101 & 41.2 \\
\cline { 2 - 4 } & 20 years & 72 & 29.4 \\
\hline
\end{tabular}

The table explains that based on gender, respondents dominated by women is as much as $52.2 \%$. This suggests that the ability to provide quality service to the community at the Maros technical working units tends to do better when done by women. Based on the age level, the respondents in the dominance of the age range from 35.1 until 45 years, it is clear that civil servants are at a very mature age range so that the respondents have the ability to think and act well in providing quality service to the community. The education level of respondents was dominated by civil servants with a bachelor latest education so that they have the ability to perform the job well. Finally, the respondents in the dominance of the civil service civilian who has a service life 11-20 years, these conditions explain that respondents have enough experience to do the job.

\section{Result Analysis of Structural Equation Modeling (SEM)}

The results of the test path diagram of a structural model full model in the model, which is used as a basis for comparison of the suitability index models with cut-off value, subsequent to the Modification Indices. The results of testing the alignment (Goodness of fit test) can be demonstrated are presented in the following table:

Table 2. Goodness of fit test

\begin{tabular}{|l|c|c|c|}
\hline Criteria Suitability Model & Suitability Index Model & Cut-off Value & Description \\
\hline Chi-square $(\mathrm{df}=121)$ & 447.945 & Small $(<450.806)$ & Good \\
\hline probability & 0.060 & $\geq 0.05$ & Good \\
\hline RMSEA & 0.021 & $\leq 0.08$ & Good \\
\hline CMIN /DF & 1.112 & $\leq 2.00$ & Good \\
\hline GFI & 0901 & $\geq 0.90$ & Good \\
\hline AGFI & 0871 & $\geq 0.90$ & Marginal \\
\hline$C F I$ & 0985 & $\geq 0.95$ & Good \\
\hline TLI & 0.982 & $\geq 0.95$ & Good \\
\hline
\end{tabular}

The table below is the result of the final model analysis showed that the overall model fit indices obtained have shown a good model fit indices marginally, chi-square, Probability, RMSEA, GFI, TLI and CFI can provide support for the good of the model. Thus the proposed research model as a whole based on the theory can be accepted (supported by empirical data in the field) so the result is fit ,then the model can already be said to be good or the development of conceptual models and theoretical hypotheses can be said to be supported by empirical data.

$\mathrm{H}_{1 \mathrm{a}} \quad$ Leadership has a positive and significant effect on employee job satisfaction 
Calculation result of the critical ratio (CR) of t-statistic larger than t-table $(2.402>1.96)$ and the probability value $(\mathrm{p})$ is smaller than $0.05(0.016<0.05)$, indicating that both variables have a significant causal relationship. Under the leadership path coefficients that have a positive influence and significant to increase job satisfaction, characterized by the path coefficient of 0.147. These results explain that a leader must be able to influence their followers towards the achievement of objectives.

Each organization has its intended purpose and that purpose by leaders perform a variety of ways to influence his followers into organizational goals achievement. The findings of this study support the findings of previous investigators, that leadership is a significant and positive effect on employee job satisfaction (Suryana et al., 2009; Omar, WW, 2013; Belias, \& Koustelios, 2014; Indra Hidayatullah, 2014).

$\mathrm{H}_{1 \mathrm{~b}} \quad$ Leadership has a positive and significant impact on employee performance

Calculation result of the critical ratio critical ratio (CR) or t- statistic is smaller than t-table ($1.173<1.96)$ and the probability value $(\mathrm{p})$ is greater than $0.05 \quad(0.241<0.05)$, indicating that the two variables do not have a significant causal relationship. Under the leadership path coefficient that gives a negative influence and not significant to employee performance, marked by the path coefficient of -0.061 . Leadership and no significant negative effect on the performance of employees in the regional work units at Maros district government can be proved. These results explain that the low ability of leaders in carrying out its duties and functions result in a lower performance of employees.

The results support the findings of Putu Sunarcaya (2008) that the leadership was not significant influence on employee performance, then denied the findings of other researchers that leadership has a positive effect on employee performance (Thoyib, A., 2005; Nur Azlina, 2007; Kistoyo 2008; Handri Wahyuni 2008; Sukardi, 2009; Suryana et al., 2009; Abbas \& Yaqoob, 2009; Twelve, J, 2013).

$\mathrm{H}_{2 \mathrm{a}} \quad$ Organizational culture has a positive and significant effect on employee job satisfaction

Based on the critical ratio critical ratio (CR) or t-statistic is greater than t-table $(2.147<1.96)$ and the probability values $(\mathrm{p})$ less than $0.05(0.032>0.05)$, indicating that both variables have a significant causal relationship. Based on that path coefficients Work Culture have a positive influence on job satisfaction of employees, marked with the path coefficient of 0.162 .

These results explain that there are significant positive and significant correlation between organizational culture and job satisfaction of employees so that it can be stated that organizational culture contribute significantly to increased employee satisfaction. The findings of this study support the findings of other researchers, that the organizational culture has a positive and significant effect on job satisfaction (Soedjono, 2005; Abdullah, 2006).

$\mathrm{H}_{2 \mathrm{~b}} \quad$ Organizational culture positive and significant impact on employee performance

The results for the calculation of the critical ratio (CR) or t-statistic is smaller than t-table $(0.321$ $<1.96)$ and the probability value $(\mathrm{p})$ is greater than $0.05(0.748>0.05)$, indicating that the two variables do not have a significant causal relationship. The path coefficients of the organizational cultures have a positive on the performance, marked by the path coefficient of 0.321 .

Organizational culture has a positive but not significant effect on employee performance, so it can be stated that organizational culture does not make a significant contribution in improving employee performance. The results of this study differs from other research findings that 
organizational culture has a significant effect on employee performance (Ma'rifah, D., 2004; Thoyib, A., 2005; Soedjono, 2005; Abdullah, 2006; Tjahjono, BN, 2006).

$\mathrm{H}_{3 \mathrm{a}} \quad$ Motivation of positive and significant effect on employee job satisfaction.

The result of the calculation of the critical ratio (CR) or t- statistic is greater than t-table (5.558> $1.96)$ and the probability value (p) is smaller than $0.05(0.000<0.05)$, indicating that both variables have a causal relationship significant. The work motivation has a positive and significant effect on job satisfaction, characterized by the path coefficient of 0.391 .

Work motivation positive and significant impact on job satisfaction of employees, employees have a high motivation in performing their duties so as to provide a real impact on the increase in employee satisfaction. These findings support the results of previous research studies, that motivation positive and significant impact on job satisfaction (Suryana et al. 2009; Arifin et al., 2015; Juniantara \& Riana, 2016).

$\mathrm{H}_{3 \mathrm{~b}}$ : Work motivation has a positive and significant effect on employee performance

The value of critical ratio (CR) or t-statistic larger than t-table (5.293>1.96) and the probability value $(p)$ is smaller than $0.05(0.000<0.05)$, indicating that both variables have a significant causal relationship. Based on the results of path coefficient it can be stated that the motivation of making a positive impact on performance, marked by the path coefficient of 0.352 .

Work motivation positive and significant impact on the creation of employee performance, that high employee motivation and employee well demonstrated significant effect on employee performance improvement. The study findings support the results of previous research studies, that motivation has a positive effect on employee performance (Ma'rifah, D., 2004; Tjahjono, BN, 2006; Faith S., 2007; Nur Azlina, 2007; Putu Sunarcaya 2008; Handri Wahyuni 2008; Sukardi, 2009; Suryana et al., 2009; Prihantoro, A., 2012; Juniantara \& Riana, 2016; Murgianto et al.,2016).

$\mathrm{H}_{4}$ : Job satisfaction has a positive and significant effect on employee performance

Calculation of the critical ratio $(\mathrm{CR})$ or t-statistic larger than t-table $(7.158>1.96)$ and the probability values $(\mathrm{p})$ less than $0.05(0.000<0.05)$, indicating that both variables have a significant causal relationship. Based on the path coefficient value can be stated that job satisfaction have a positive influence on employee performance marked the path coefficient of 0.524. Job satisfaction and significant positive effect on employee performance, that if an employee is satisfied with his work, its performance will increase. This study supports the findings of previous investigators, that job satisfaction is positive and significant effect on employee performance (Jati, SP, \& Darmawan, D., 2005; Abdullah, 2006; Syaiin, S., 2008; Suryana et al.,2009; Asteria Putri \& Latrini, 2013; Arifin et al., 2015; Juniantara \& Riana,2016).

$\mathrm{H}_{5 \mathrm{a}} \quad$ Leadership has a positive and significant impact on performance through employee satisfaction

The hypothesis testing showed that leadership has a positive effect on performance through employee satisfaction declared rejected or not supported by empirical facts, that based on the results of the calculation of the path coefficients indicate that the two variables do not have a significant causal relationship. Based on the path coefficient value can be stated that the leadership does not give effect to the performance of employees through employee satisfaction with the path coefficient value of 0.077 . 
A significant difference between leadership and employee performance through job satisfaction cannot be proved. These results illustrate that a leader must understand exactly what should be done so that the impact on the creation of employee performance. The study's findings differ from previous research findings, that leadership is positive and significant impact on the extra role performance through job satisfaction (Yun, S. et al., 2007; Omar, WW, 2013).

$\mathrm{H}_{5 \mathrm{~b}}$ : Organizational culture positive and significant impact on performance through employee satisfaction

Following the hypothesis which states that the organizational culture has a positive and significant effect on performance through employee satisfaction declared is rejected or not supported by empirical facts. Based on the calculation coefficient lines provide evidence that the two variables do not have a significant causal relationship. Path coefficient value of organizational culture does not have a significant influence on employee performance through job satisfaction as evidenced by the path coefficient value of 0.085 .

Organizational culture was not significant effect on employee satisfaction, so that the hypothesis be rejected or not supported by empirical facts. These results illustrate that organizational culture does not contribute in enhancing performance through job satisfaction. The result of this study differs from previous research findings, that organizational cultures significantly influence organizational performance through satisfaction (Soedjono, 2005).

$\mathrm{H}_{5 \mathrm{c}} \quad$ Work motivation positive effect on performance through employee satisfaction

Work motivation has a positive effect on performance through employee satisfaction, the hypothesis is rejected or otherwise not supported by empirical data. Based on the path coefficient value can be explained that motivation had a positive influence, but no significant effect on the performance of employees through job satisfaction as evidenced by the path coefficient value of 0.245. These results support the findings of previous studies, that job satisfaction act as a mediating variable in analyzing the effect of work motivation on performance (Murgianto et al., 2016).

\section{Conclusions and recommendations}

The process of leadership that is run leader proved to have a positive influence and significant to increase job satisfaction, that a leader must be able to influence their followers towards the achievement of the goal, but on the other side of leadership gives a negative influence and no significant effect on improving the performance of employees, that that low ability of leaders in carrying out its duties and functions result in a lower performance of employees. Cultural organizations contribute significantly to increased employee satisfaction, but in generating high employee performance proved that organizational culture is not able to make a significant contribution in improving employee performance.

Work motivation and a real positive effect in raising employee satisfaction, employees have a high motivation in performing their duties so as to provide a real impact on the increase in employee satisfaction. The same fact also explains that motivation positive and significant impact on the creation of employee performance, high motivation and employee well demonstrated significant effect on employee performance improvement. Job satisfaction and significant positive effect on employee performance, that if an employee is satisfied with his work, the performance of the display will increase. 
A leader must understand exactly what should be done so that the impact on the creation of employee performance. In the execution of the instruction, consultation, participation and delegations gave no significant effect on employee performance in carrying out its work through job satisfaction.

Organizational culture does not contribute in improving the performance of employees through job satisfaction. Employees who got the attention to the final outcome of work and obedience work, innovation, detail / accuracy in work, results orientation, employee morale and aggressiveness, satisfaction and consistently not been able to improve the performance of employment. Work motivation had a positive influence, but no significant effect on the performance of employees through job satisfaction. Implementation of their career path, a pleasant working environment, and their motivation for satisfaction (reward), responsibility, and self-development will encourage employees to improve their performance.

Improving the quality of services performed by employees can be done continuously provide opportunities and greater opportunities for all employees to follow the development of knowledge through higher education.

Creation of job satisfaction and employee performance can be achieved through efforts of leaders to remain reward or appreciation to employees who excel through salaries and wages according to the workload, social security administration, interpersonal rewards and opportunities for promotion.

\section{References}

Abbas, Q., \& Yaqoob, S. (2009). Effect of leadership development on employee performance in Pakistan. Pakistan Economic and Social Review, 269-292.

Abdulloh, A. (2006). The influence of organizational culture, locus of control and job satisfaction on the performance of employees at the Tax Office West Semarang (Doctoral dissertation, Diponegoro University).

Arifin Syamsul., Adenan, and Khairunnisa (2015) .Relationship and Nurse Perception about the Leadership of Hospital Nurses towards Work Satisfaction Director at In-patient Hospital Installation Queen Zalecha, Maratapura. Asian Journal of Applied Sciences. Vol. 3, No. 3

Asteria Putri, PY, and Latrini, MY (2013). Effect of Job Satisfaction on Employee Performance Public Sector, with In-Role Performance and Innovative Performance as variable Mediation. E-Journal of Accounting, 5 (3), 627-638.

Twelve, J. (2013). The leadership style and the productiveness of employees in the banking sector in Slovakia. Journal of Competitiveness, 5 (1).

Belias, D., \& Koustelios, A. (2014). Transformational leadership and job satisfaction in the banking sector: A review. International Review of Management and Marketing, 4 (3), 187.

Jati, SP, \& Darmawan, D. (2005). Effect of employee performance to satisfaction, trust and customer loyalty. Journal of Management and Entrepreneurship, 7 (1), 48.

Handoko, Hani T., (1992). Personnel Management and Human Resources. Second Edition,

Hendri Wahyuni (2008). Effect of Leadership and Motivation on Employee Performance at Grand Zuri Pekanbaru, Thesis, University of Riau.

Sukendar Faith (2007), Effect of Motivation and Training on Employee Performance at Pelalawan District Forestry Office. Thesis, Graduate Program, Master of Public Administration Program, University of Padjadjaran in Bandung.

Indra Hidayatullah (2014). Leadership influence on the performance of employees in the human resources department at PT. Bukit Asam (Persero) Tbk, Tanjung Enim. Undergraduate Theses. Universitas Bina Darma 
Istianto, Bambang. (2009). Government management in the Perspective of Public Service. Jakarta: Partners Media Discourse

Juniantara, IW, \& Riana, IG (2016). Effect of motivation and job satisfaction to employees performance of cooperatives in Denpasar. E-Journal of Economics and Business, University of Udayana, 4 (09).

Kartono. Kartini (2001) . Leader and Leadership, PT. Raja Grafindo Persada, Jakarta.

Kistoyo. (2008). Influence of Leadership, Communication and Physical Environment on Employee Performance in Pekalongan District Education Office. Unpublished thesis. Surakarta: Graduate University of March

Luthans, Fred, (2002). Organizational Behavior, Issue 10, Publisher Andi, Yogyakarta.

Ma'rifah, D. (2004). Effect of employee motivation and organizational culture on the performance of social workers in technical and operational units of social services East Java province. Surabaya University Press.

Mangkunagara, Anwar King (2000). Human Resource Management Company, PT. Remaja Rosda karya, Bandung

Mangkunagara, Anwar King (2005). Human Resource Management. PT. Gramedia, Jakarta.

Moch.As'ad, (1995). Industrial psychology. Jakarta: Liberty.

Muchinsky, Paul M., (1997). Psychology Applied to Work, $1^{\text {st }}$ Edition, The Dorsey Press, Chicago

Murgianto, Siti Sulasmi \& Suhermin (2016). The Effects of Commitment, Competence, Work Satisfaction On Motivation, And Performance of Employees At Integrated Service Office of East Java. International Journal of Advanced Research (IJAR). Volume 3, Issue -378396

Nur Azlina, (2007). Analysis of the Relationship Between Leadership and Motivation of Civil Servants with employee performance Siak district, the journal of accounting and auditing. Vol.3 (2) UNDIP.

Omar, WW (2013). Transformational leadership style and job satisfaction relationship: a study of structural equation modeling (SEM). International journal of academic research in business and social sciences, 3 (2), 346.

Government of the Republic of Indonesia. (1999) Act No. 22, 1999. On Local Government, Bandung: Primary Kuraiko

Government of the Republic of Indonesia. (1999) Act No. 25 of 1999. On Local Government, Bandung: Primary Kuraiko

Government of the Republic of Indonesia. (2004) Law No. 32 of 2004. On Local Government, Bandung: Primary Kuraiko

Government of the Republic of Indonesia. (2004) Law No. 33 of 2004. About About balance between the Central Government and the Regions, Bandung: Primary Kuraiko

Government of the Republic of Indonesia. (2014) Law No. 33 of 2004. About On Local Government, Bandung: Primary Kuraiko

Maros Regency Regulation (2012). No. 11 Year 2012 on Organization and Work Procedure Regional Offices Scope of Government Maros (Maros Regional Gazette of 2012 No. 11).

Prihantoro, A. (2012). Human Resources Performance Improvement Through Motivation, Discipline, Work Environment, and Commitment. Value Added. Magazine of Economics and Business, 8 (2).

Robbins, Stephen P., (2001), Organizational Behavior, Concepts, Controversies, Applications, Interpreting Hadyana Pujaatmaka and Benyamin Molan, Prenhallindo, Jakarta

Robbins, Stephen. P. (2006). Organizational behavior. Tenth Edition Indonesian. PT Gramedia Group Index. Jakarta

Soedjono, S. (2005). Influence of Organizational Culture and Organizational Performance Against Employee Satisfaction on Public Passenger Terminal in Surabaya. Journal of Management and Entrepreneurship, 7 (1), 22-47 
Sperling, Abraham (1987). Psychology: Made Simple, London, The Publisher WH Allen \& Co. Ltd.

Stanton, William J. (1981). Fundamentals of Marketing. New York: McGraw Hill International

Sukardi (2009), Effect of Leadership and motivating to work achievement extension agents at the Department of Animal Husbandry and Fisheries Siak. Thesis, Graduate Program, Master of Public Administration Program, University of Padjadjaran Bandung

Sunarcahya, P. (2008). Analysis of Factors Affecting Employee Performance in Environmental Health Office Alor district, East Nusa Tenggara (Doctoral dissertation, The Open University).

Suryana, N., Haerani, S., \& Taba, MI (2010). Influence Leadership and Work Motivation on Employee Satisfaction and Corporate Performance (Case Study In the Mining Division of PT. Inco Sorowako). Journal of Management and Entrepreneurship.

Syaiin, S. (2008). The influence of job satisfaction on employee performance Medan Bestari specialist clinic. University of North Sumatra, Medan.

Thoyib, A. (2005). Relations Leadership, Culture, Strategy, and Performance: Concept Approach. Journal of Management and Entrepreneurship, 7 (1), 60.

Tjahjono, BN (2006). Influence of Work Motivation and Organizational Culture on Employee Performance in the Environment Department of Highways Central Java (Doctoral dissertation, University of Muhammadiyah Surakarta).

Tsui, United States, Pearce, JL, Porter, LW, and Tripoli, AM (1997). Alternative Approaches to The Employee-organization Relationship: Does the investment pay off? Academy of Management Journal, 40, 1089-1121.

Walker, Domascus, (2007). Organizational Behavior in Characteristic Qualified. Prentice Hall Cliffs, New Jersey.

Yun, S. Cox, J., Sims Jr., HP, \& Regards, S. (2007). Leadership and teamwork: The effects of leadership and job satisfaction team on citizenship. International Journal of Leadership Studies, 2 (3),171-193. 